\title{
Vejledning - mellem magt og afmagt
}

\author{
Gerd Christensen, lektor, cand.mag., Institut for Medier, Erkendelse og Formidling, Afdelingen for \\ Padagogik, Kobenhavns Universitet
}

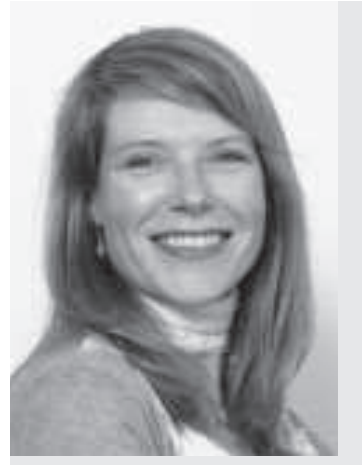

Gerd Christensen er cand mag. i psykologi og filosofi samt exam. pæd. Er ansat som lektor i pædagogik på Institut for Medier, Erkendelse og Formidling, Københavns Universitet. Forsker i problemorienteret projektarbejde i grupper samt i videnskabsteoretiske og metodologiske forhold vedrørende humanistisk og sam-

fundsvidenskabelig forskning.

Norvarende artikel er en empirisk funderet diskussion af vejlederens rolle og funktion i projektarbejdet, sådan som det praktiseres på to videregående uddannelser. Da der ikke eksisterer generelle normer for god vejledningspraksis, er det scerligt interessant at lytte til, hvordan de studerende definerer dette. I artiklen defineres 'den gode vejleder' ud fra de studerendes fortallinger om, hvordan 'den dårlige vejleder' dominerer eller overlader de studerende til sig selv. At vejlederen samtidig er bedommer af projektet illustrerer, at vejlederen eksisterer i et felt mellem magt og afmagt.

\section{Projektarbejde på universitetet}

Projektarbejde har igennem de seneste 30 år bredt sig fra en relativt isoleret position i det pædagogiske felt til at være en pædagogisk aktivitet, der gennemføres på alle niveauer i uddannelsessystemet fra folkeskole til videregående uddannelser. Projektarbejde struktureres over principperne projektorientering, problemorientering, tværfaglighed og eksemplarisk læring samt et princip om deltagerstyring og gruppearbejde. Hermed sker tillige en forskydning af lærerrollen fra underviser til vejleder; en position, der, som det ses af nærværende artikel, er langt fra at være problemfri.

Artiklen bygger på en empirisk undersøgelse af projektarbejde på Humanistisk Basisuddannelse (HUMBAS) på Roskilde Universitetscenter (RUC) og
SPRØK uddannelsen på Copenhagen Business School (CBS). Undersøgelsen omfatter spørgeskemaer, kvalitative interviews samt observationer af to gruppers arbejde igennem et projektforløb af et semesters varighed. Artiklen indeholder uddrag fra interviewene. Analysestrategien er funderet i poststrukturalisme og socialkonstruktionisme. Det vil i korte træk sige, at analyserne fokuserer på diskurs som 'de sagte ting' ud fra forholdet mellem inklusion og eksklusion og den måde, hvorpå dette skaber betydning for de implicerede aktører.

\section{Den uklare vejlederrolle}

Når læreren bliver vejleder, betyder det for det første, at undervisningen flyttes fra klasserummets offentlige forum til en mere intim position i grupperummet (Saugstad, 2004). Her skal undervisningsindholdet for det andet målrettes gruppens konkrete behov i relation til det igangværende projekt, et forhold, der stiller andre - og øgede - faglige krav til underviseren i form af en målretning og individualisering af undervisningsindholdet. For det tredje er der, som det foreligger nu, ingen standarder for vejlederfunktionen. Den er med andre ord uklart defineret.

Dette kommer i min undersøgelse til udtryk i de studerendes beretninger om, hvordan rollen fortolkes meget forskelligt af forskellige vejledere. Alle de studerende, jeg har talt med, giver udtryk for, at der er mange måder at være vejleder på - et fænomen, der bekræftes af vejlederne selv. Der er således forskel på, hvordan og hvor meget vejlederne engagerer sig fagligt i gruppens projekt og i dens arbejdsmæssige og gruppedynamiske proces, ligesom der er forskel på, hvor meget de blander sig, uden at de inviteres til det af de studerende. Dette udtrykkes således af to studerende på HUM-BAS:

Asger: Der ikke noget, der er almindeligt for en vejleder - altså, de har alle sammen deres unikke holdning til det, og det virker ikke som om, der er nogen...

Pernille: ... regel... 
Dette svarer til de undersøgelser, der tidligere er lavet på området. Konklusionen på en litteratursøgning med fokus på evidensbaserede studier af vejledning, som Wichmann-Hansen m.fl. (2007) har foretaget, lyder således tilsvarende:

Den gennemgående konklusion, som kan udledes på tvars af de 50 inkluderede referencer, er vel netop, at vejlederrollen udfyldes meget forskelligt afhoengigt af den enkelte vejleders personlighed, ligesom variationen mellem studerende betyder, at de forventer og vardsatter forskellige vejlederroller. (ibid., s. 16).

Tilsvarende anfører Kolmos og Kofoed at: Vejlederrollen er som udgangspunkt et helt personligt anliggende for underviseren. Selv om projektarbejdsformen har eksisteret $\mathrm{i}$ mere end 25 år er der fortsat ingen eksplicitte og formaliserede anvisninger på, hvordan man forvalter den komplekse rolle som vejleder« (Kolmos \& Kofoed, 2002, s. 10).

Til trods for at vejlederfunktionen udfyldes meget forskelligt, peger mit materiale på nogle fællestræk i de studerendes forståelser af, hvad der kendetegner 'den gode vejleder'. Disse kommer til udtryk igennem den måde, hvorpå de studerende definerer 'den dårlige vejleder', hvorfor de vil blive indkredset sådan i det følgende.

\section{Kompetencer og beføjelser}

I princippet skal projekterne på HUM-BAS formuleres inden for en ramme, hvor der er vejlederkompetencer til rådighed $\mathrm{i}$ det 'hus', hvor de studerende hører til. Imidlertid betyder det projektpædagogiske ideal om tværfaglighed samt det, at projekterne skal tage udgangspunkt $i$ 'et problem' og i de studerendes interesser, at projekterne har en betydelig faglig bredde. ${ }^{1}$ Derfor er det ikke altid muligt at finde en bestemt faglighed i projekterne, der kan knytte an til en bestemt vejleders faglighed. Af samme årsag er der ofte grupper på HUM-BAS, der får tildelt vejledere, hvis faglige og forskningsmæssige interesser er relativt forskellige fra dem, gruppen umiddelbart efterspørger i deres projekt.

Det forhold, at vejlederen underordnes projektemnet, udtrykkes af en studerende med ordene: "Man har et projekt og far en vejleder". Ofte betragtes dette som en fordel - om end de fleste studerende foretrækker at få tildelt en vejleder, hvis faglige kompetencer er i overensstemmelse med dem, der efterspørges i projektet. Når man betragter udgangspunktet i projektet som en fordel, begrundes det med, at vejlederkompetencer i betydelig grad er generelle, samt at projektarbejdet er deltagerstyret, hvorfor det er gruppen og ikke vejlederen, der skal drive projektarbejdet både fagligt og socialt (se ligeledes Kolmos \& Holgaard, 2007).

Dette giver sig helt konkret udslag i, at nogle af de studerende kan berette om at skulle klare sig igennem et projektarbejde uden ret megen faglig vejledning. I en af de grupper, jeg interviewede på HUM-BAS, italesatte man vejlederen som 'stort set mere en belastning, end han var til gavn', hvorfor gruppen valgte at 'skære ham fra' og kun i minimal grad benytte muligheden for vejledning.

\section{Illegitime vejledere}

Når de studerende på HUM-BAS skal begrunde, hvorfor de vælger at 'skære vejlederen fra', sker det ikke kun med reference til vedkommendes manglende faglige indsigt $\mathrm{i}$ deres projekt. Fortællingerne om 'at skære vejlederen fra' går mindst lige så meget ud på, at vejlederen - ifølge de studerendes fortællinger - blandede sig for meget og 'ville bestemme' over projektet:

Asger: Ja. Men sidste semester så jeg også et problem $i$, at det ikke kun var et spørgsmål om, at han lukkede lort ud. Det var også et spørgsmål om, at han ikke var enig $i$ at projektet skulle laves på den måde, som vi ville lave det [...]

Jørgen: Han vidste hele tiden, hvordan vores projekt skulle være.

Asger (taler ind over): ... det lå ligesom i luften, at alt hvad vi lavede, det var bare forkert.

Som det her fremgår, er der en hårfin balance i forholdet mellem, hvornår vejledning bliver betragtet som vejledning, og hvornår den bliver betragtet som utidig indblanding og dominans.

Jens Tofteskov og Anette Kolmos har foretaget en kategorisering af vejledere i fire kategorier: Procesvejlederen, produktvejlederen, laissez-faire vejlederen og kontrolvejlederen (Tofteskov, 1996; Kolmos \& Holgaard, 2007; Kolmos \& Kofoed, 2002). Den vejleder, der berettes om i ovenstående interviewuddrag, kan ud fra de studerendes beretning kategoriseres som produktvejlederen:Vejlederen føler ejerskab til projektet og driver de studerende ud fra egne ambitioner (ibid.). I ovenstående beretning kompliceres forholdet imidlertid af, at de studerende ikke alene italesætter det som utidig indgriben $\mathrm{i}$ forhold til projektet, men også i forhold til dem som personer. Pernille fra gruppen udtrykker det således: "Ja, ja de burde være der til at vejlede os og ikke til at fortælle os, hvordan man skal være ... det burde vi jo være gamle nok til... eller dygtige nok til efterhånden at kunne finde ud af".

De studerende italesætter vejledningen som så overgribende og patroniserende, at det decimerer dem til umodne væsner eller 'børn', som ikke er i stand til at forvalte det komplekse og krævende arbejde med projektet. Vejlederfunktionen kan således ikke alene betragtes som en faglig funktion; de studerende forstår den som personligt evaluerende og opdragelsesmæssig - nærmest 'forældreagtig'. Meget tyder på, at de 
studerende på HUM-BAS forveksler produktvejlederen med kontrolvejlederen. Dette er formentlig følgen af, at de studerende opererer med andre kriterier, der drejer sig om deltagelse og personlig vurdering.

Tilsvarende fortællinger om dominerende vejledere finder jeg således overalt i mit interviewmateriale fra HUM-BAS. I nedenstående interviewuddrag fremstilles en vejledning, som tydeligvis er produktorienteret, som et 'skrækscenarium':

Carl: Ja, det må være skrækscenariet, hvis man får en vejleder som nærmest ligesom vil bestemme, hvordan det hele skal gøres...

Marianne: Og som har et pensum ikk'.

Carl: ... Ja, og som siger: Men I må ikke bruge de bøger. I skal ikke vælge de emner, men dette emne. Det har man da hørt skrækhistorier om...

Marianne: Ja, det har man da hørt, at nogle af vejlederne gør.

Som det fremgår, florerer en række myter på RUC om dominerende vejledere; myter, som regulerer såvel de studerendes som vejledernes aktivitet i relation til, hvad legitim og illegitim vejlederadfærd er. Også her defineres vejledere, der 'vil bestemme' og 'overtrumfe' som vejledere, der ikke lever op til intentionerne om deltagerstyring i projektarbejdet. Begrebet 'pensum', der knyttes til denne vejledertype, konnoterer i denne sammenhæng 'gammeldags pædagogik', 'traditionel enkeltfaglighed', 'fastlåsthed mod et resultat' og 'manglende villighed til at lade de studerende eksperimentere'.

Det er imidlertid interessant, at 'den dominerende vejleder', dvs. produktvejlederen, ikke italesættes som et problem på SPRØK, hvor der synes at være meget videre beføjelser for vejlederens faglige indblanding $\mathrm{i}$ projekterne. Her forventer de studerende derimod, at vejlederen er fagligt kompetent i relation til projektets emnefelt. Når dette er tilfældet, kan det skyldes, at projekterne på SPRØK er meget klarere definerede inden for en begrænset fag- og emnekreds end projekterne på HUM-BAS. Dermed făr vejledningen mere karakter af fagorienteret vejledning end af problemorienteret vejledning (Kolmos \& Kofoed, 2002; Kolmos \& Holgaard, 2007).

\section{En anden illegitim position}

Dermed fremstår det skisma, som vejlederen befinder sig i: På den ene side må han ikke dominere; på den anden side kan han nemt falde $i$ den anden af de problematiske vejlederkategorier: 'Den uengagerede vejleder', som beskrives således af en studerede fra HUM-BAS:

Vi havde det lidt anderledes. Vi havde næsten ikke nogen vejledermøder, fordi [årsager til vejlederens fravær]. Når vi mødtes, så havde han ikke læst på det. Men altså, vi havde faktisk meget brug for ham sådan set. Det havde været rigtig godt, hvis vi havde haft ham, og han kunne have bidraget med noget, det er jeg sikker på [...] og hjulpet med nogle konflikter, vi havde og sådan noget [...] Så vi ville gerne have brugt vores vejleder, men kunne altså ikke.

Samtidig med at de studerende er enige om, at vejlederen ikke 'skal bestemme', italesættes en fraværende eller 'vag vejleder' således også som et problem. 'En vag vejleder' er kendetegnet ved ikke at give ærlig faglig feedback på de studerendes arbejde. En anden studerende udtrykker det således: »Og nogen siger, det er godt lige meget, hvad man har lavet [...] Selv om man godt ved at, nej altså, det er ikke godt, det de to har siddet og lavet«. Den vage vejleder er laissez fairevejlederen.

'En dårlig vejleder' på RUC er en vejleder, der har overskredet grænserne mellem legitim og illegitim adfærd - ikke nødvendigvis ved ikke at være fagligt kompetent, men ved at 'ville bestemme for meget' over de studerendes projekter eller ved at være for 'vag'. I begge tilfælde truer han idealet om lighed mellem studerende og vejleder: Er han for dominerende, dvs. er han produktorienteret i sin vejledning, hører han nok slet ikke til på RUC (Frello, 1996). Er han for vag, dvs. laissez faire i sin vejledningsstil, trues idealet indirekte, idet der rettes fokus mod gruppens krav om at få vejledning - trods alt.

Mens de studerende forventer, at vejlederne giver dem vide beføjelser og behandler dem som kompetente, voksne mennesker eller endda 'forskere', forventes vejlederen at give faglig kritik og i visse tilfælde endog fungere som den 'overdommer', som den studerende ovenfor synes at efterlyse, og som direkte italesættes som en af vejlederens funktioner af de studerende på SPRØK.

\section{Den gode vejleder}

Antropologen Cathrine Hasse har kunnet identificere, hvordan 'den gode underviser' på fysikstudiet blev anvendt som målestok for evaluering og udpegning af den dårlige (Hasse, 2002). I mit materiale fremgår den modsatte bevægelse, hvilket vil sige, at 'den gode vejleder' $i$ et betydeligt omfang er defineret igennem en normativ forskelssætten til den dårlige.

Dette hænger muligvis sammen med, at der ikke eksisterer eksplicitte retningslinjer for, hvordan man 'er vejleder'. Dermed er det umiddelbart vanskeligt at definere 'den gode vejleder'. Det er op til den enkelte vejleder at prøve sig frem - blandt andet ved at lytte til de myter, som distribueres af de studerende, og som definerer grænserne for vejlederens beføjelser. Det er herigennem, man vil kunne forme sin vejledningsstil sådan, at den genkendes som legitim af de studerende. 
På HUM-BAS defineres 'den gode vejleder' dels som forskellig fra de vejledere, der vil 'dominere', 'overtrumfe' og 'stjæle problemet fra de studerende', dels som forskellig fra de vejledere, der er 'vage' og 'ligeglade'. 'Den gode vejleder' er i stand til at 'være lærer' og vejlede med hensyn til litteratur og give 'et lille foredrag', når det er påkrævet - men vel at mærke et lille et, som gruppen ikke tolker som et forsøg på dominans:

Jørgen: For at nævne et andet eksempel, så havde vi jo [vejledernavn] i det forste projekt, og hun var helt anderledes [...] Hun havde ikke altid styr på reglerne $[\ldots]$ men til gengæld, gav hun os altid lige præcis det litteratur... vi havde brug for

$[\ldots]$

Pernille: Ja, hun var sindssygt god

Ole: Og så fortalte hun os også meget om de ting, vi gerne ville vide noget om - så fik vi sådan et lille foredrag. Det var...enormt godt.

Jørgen:Ja, men netop et lille et, fordi [vejledernavn] han var sådan en, der talte $\mathrm{i}$ halvanden time.

Vejlederens manglende indblik i konventioner i forbindelse med projektets opbygning italesættes ikke som problematisk. 'Den gode vejleder' er fagligt versatil og mestrer tværfagligheden. Det betyder, at 'den gode vejleder' er i stand til at lægge tilstrækkelige bånd på sin faglige interesse (og viden) til, at denne ikke opleves som et ønske om dominans og kontrol. Lykkes dette, foretrækker de studerende fagligt kompetente vejledere. Dette også selv om vejlederkompetencer i et vist omfang betragtes som generelle.

'Vejlederfaglighed' på RUC er således ikke alene et spørgsmål om faglige kompetencer, men synes snarere at være en funktion af personligt engagement. 'Den gode vejleder' er således både fagligt og personligt engageret i de studerendes projekter; et engagement, der menes at kunne smitte af på de studerende og øge deres motivation. I nogle sammenhænge fortæller de studerende det endog som en fordel, hvis de 'på nogen punkter ved mere end vejleder', som det udtrykkes. På denne måde er vejlederen 'måske bedre på niveau med os'. 'Den gode vejleders' kompetencer ytrer sig ved at lade de studerende eksperimentere og begå fejl, men alligevel skabe genveje eller 'skære nogle grene af', som det udtrykkes af de studerende. 'Den gode vejleder' giver de studerende modspil og konstruktiv kritik uden at orientere sig mod et pensum.

Endelig er 'den gode vejleder' en, man teoretisk set ville kunne gå til med gruppens interne problemer og konflikter; en mulighed, som dog sjældent benyttes. Skal man benytte sig heraf, skal konflikterne have et fagligt aspekt. Så selv om 'den gode vejleder' er en, man kunne forestille sig som konfliktmægler, opfattes det ikke som et problem, at vejlederen ikke besidder kompetencer hertil. 'Den gode vejleder' på RUC defi- neres med andre ord som procesvejlederen, uanset om kompetencerne hertil måtte mangle.

Et mindre komplekst billede af 'den gode vejleder' tegner der sig på SPRØK. Selv om de studerende også her forventer et vist omfang af lydhørhed og 'pædagogiske kompetencer', hvilket vil sige vejlederens lyst og evner til at agere procesvejleder, vægtes det faglige indhold i større omfang. Dette ses også af, at eksperter fra erhvervslivet uden pædagogisk indsigt kan fungere som projektvejledere her. For de studerende på SPRØK synes projektskrivning og vejledning at handle om at få udfærdiget et godt projekt og få en god karakter. 'Den pædagogiske kompetence' betragtes blot som et ekstra plus ved vejlederen. 'Den gode vejleder' på SPRØK er med andre ord produktvejlederen.

\section{Vejledning og bedømmelse}

Vejlederrollen stiller imidlertid også andre udfordringer til underviseren $\mathrm{i}$ forbindelse med eksamen og bedømmelse. Dette er en alment kendt problematik, hvilket fremgår af litteraturen om vejledning (Kolmos \& Kofoed, 2002; Kolmos \& Holgaard, 2007; Handal \& Lauvås, 2007; Rienecker m.fl., 2005).

På RUC fortæller flere vejledere, hvordan de selv har haft følelsen af at være til eksamen, når de grupper, de har vejledt, fremlægger deres projekter (Frello, 1996). Dette kommer sig af, at der er en praksis på HUMBAS om, at grupperne følges tæt af deres vejleder. Denne praksis vil sædvanligvis medføre, at vejlederen opnår og føler et vist medejerskab til projektet.

Herved mener de studerende at kunne få en vis beskyttelse til eksamen. Muligheden for at gøre vejlederen til medansvarlig for projektet bortfalder imidlertid, hvis de studerende ikke benytter sig af vejledningen. De studerende fortæller således om, hvordan de frygter at 'blive slagtet' af en vejleder, som er 'sur' over ikke at have været inddraget. Med denne fortolkning tillægger de studerende vejlederen den adfærd og de følelser, som de selv ville have, såfremt de ikke blev involveret i deres gruppes projekt. Dette kan derfor være udtryk for, at de i visse henseender betragter vejlederen mere som et gruppemedlem end som en faglig konsulent, der pendler ud og ind af gruppen alt efter gruppens behov.

Vejlederrollen betyder således også, at undervisernes autoritet undertones eller skjules for de studerende, sådan at de 'glemmer', at vejlederne også er bedømmere af projekterne og af de enkelte studerende.

\section{Bedømmelse og magt}

Dette blev allerede fremhævet i 1980erne af uddannelsesforskerne Bo Jacobsen og Steinar Kvale. Ifølge Jacobsen og Kvale kendetegnes løst strukturerede og deltagerstyrede uddannelsesforløb som fx projektpædagogik ved, at magten har antaget mere subtile former 
end tilfældet er i mere 'traditionelle' lærerstyrede uddannelsesforløb (Jacobsen, 1981; Kvale, 1983). Mens magten i sidstnævnte ligger eksplicit hos underviseren, hævder Kvale, at der finder 'skjult vejledningsvold' sted i anti-autoritære studier som projektarbejde. Her bliver de studerende ofre for en dobbeltkommunikation, hvor de på den ene side selv ansvarliggøres for tema, problemstilling og gruppeforløb, mens det på den anden side stadig er vejlederen, der bedømmer projektets kvaliteter til eksamen (Kvale, 1983).

Modsætningen mellem vejlederens funktion som vejleder og som bedømmer af projektet fremgår ligeledes i den nutidige litteratur på området (Handal \& Lauvås, 2007; Harboe, 2007; Ulriksen, 2004). Også her pointeres den magt, der ligger i vejlederens bedømmerfunktion til eksamen. Jacobsen og Kvale lagde dog vægten på ‘den skjulte læreplan’ og således på den subtile undertrykkelse af de studerende i en pædagogik, der efter intentionen skulle være mindre undertrykkende end den traditionelle, lærerstyrede pædagogik.

Uden i øvrigt at så tvivl om Bo Jacobsens og Steinar Kvales påpegninger af vejlederens 'skjulte magt' $\mathrm{i}$ projektpædagogikken, tyder mit materiale på, at magtrelationerne er mere komplekse end som så. Ifølge mit materiale er vejlederen ikke blot centrum for magt og magtudøvelse, men i mindst lige så høj grad underlagt magten - i særdeleshed på RUC. Her eksisterer vejlederen $i$ et felt, hvor de studerende i stort omfang er i besiddelse af definitionsmagten af vejlederen som henholdsvis 'god' og 'dårlig'.

\section{Mellem magt og afmagt}

Når vejlederen er med i den endelige bedømmelse af projektet, eksisterer vejlederen i spændingsfeltet mellem magt og afmagt. På RUC kan idealer om 'deltagerstyring' og 'lighed' dels betyde, at vejlederens kompetencer stækkes, dels at vejlederen har vanskeligt ved at identificere, anvende og blive respekteret for sin faglighed og viden - ofte med frustration til følge (Frello, 1996).

Faren for at blive defineret som en illegitim vejleder kan derfor være med til at sætte grænserne for, hvorvidt vejlederen benytter sig af retten (og pligten) til at skride ind over for de studerendes arbejdsproces og fx tilkendegive, hvis man har mistanke om, at der er studerende, der ikke yder deres indsats i grupperne (Kolmos \& Kofoed, 2002). Sammen med princippet om, at gruppen udgør en helhed, kan disse normer betyde, at vejlederen undlader at differentiere karaktererne imellem gruppemedlemmerne, når der er tale om et gruppeprojekt.

Dette kompliceres yderligere af, at vejledning er en personlig relation mellem studerende og vejleder og derfor et forhold, som vanskeligt lader sig generalisere (Wichmann-Hansen m.fl., 2007; Dyste \& Samara, 2006; Lauvås \& Handal, 1998; Handal \& Lauvås, 2007; Lyngstrøm, 2007; Kolmos \& Holgaard, 2007; Kolmos
\& Kofoed, 2002; Simonsen og Ulriksen, 1998; Frello, 1996; Saugstad, 2004). Samme vejleder kan således opfattes som overgribende og 'dominerende' af nogle studerende, mens andre er tilfredse og endnu andre måske opfatter vedkommende som 'vag'.

I relation til den undervisningsmæssige praksis har min undersøgelse vist, dels hvordan den institutionelle kontekst har betydning for, hvor grænserne går imellem legitim og illegitim vejlederadfærd, og dels hvordan vejlederrollen generelt er langt mere sårbar end positionen som underviser eller lærer. Dette blandt andet af den årsag, at vejledning i modsætning til undervisning er individualiseret og curriculum etableres på de studerendes præmisser. Derfor kræver det større fagligt overblik at være vejleder end at være lærer i traditionel forstand.

Skal man også være en 'en god vejleder', kræves der tillige, at man er socialt lydhør og kan pendle imellem symmetri og asymmetri i lærer-elev forholdet. Det kræver med andre ord, at man kan navigere i rummet mellem magt og afmagt.

Tak til Lotte Rienecker for litteratur og nyttige kommentarer til en tidligere udgave af denne artikel.

\section{Litteratur}

Bjørgen, I. (1995). Ansvar for egen laering. Oslo: Tapir.

Dyste, O. \& Samara,A. (red.). (2006). Forskningsvejledning på masterog doktorgradsnivå. Oslo: Abstrakt Forlag.

Frello, B. (1996). Projektpadagogik og udviklingsarbejde på RUC. Delrapport i UNIPÆD-projektet. Roskilde: Roskilde Universitetscenter.

Frello, B. (1997). Ny larer på RUC - møde med RUC-kulturen. 9. delrapport fra UNIPÆD-projektet. Roskilde: Roskilde Universitetscenter.

Handal, G. \& Lauvås, P. (2007).Veiledning i de videregående utdannelser. Dansk Universitetspadagogisk Tidsskrift, 3, 4-10.

Harboe, T. (2007). Godkendelsesfælder i BA-projekt- og specialevejledning. Dansk Universitetspadagogisk Tidsskrift, 3, 49-53.

Hasse, C. (2002). Kultur i bevagelse. Fra deltagerobservation til kulturanalyse $-i$ det fysiske rum. Frederiksberg: Forlaget Samfundslitteratur.

Illeris, K. (1974). Problemorientering og deltagerstyring. København: Unge Pædagoger.

Illeris, K. (1981). Modkvalificeringens peedagogik. København: Unge Pædagoger.

Jakobsen, B. (1981). De højere uddannelser mellem teknologi og humanisme. København: Rhodos.

Kristensen, H. J. (1997). En projektarbejdsbog. Fra 100 udviklingsarbejder om projektarbejde. København: Undervisningsministeriet, folkeskoleafdelingen.

Kolmos, A. \& Holgaard, J. E. (2007). Situationsbaseret projektvejledning. Dansk Universitetspaedagogisk Tidsskrift, 3, 54-62.

Kolmos, A. \& Kofoed, P. (2002). Sig' det så. Projektvejledning på Universitetet. Aalborg: Pædagogisk Udviklingscenter, Aalborg Universitet.

Kvale, S. (1983). Den alternative pædagogiks skjulte læreplan. Tidsskrift för Nordisk Förening för Pedagogisk Forskning. Nr. 1/1983.

Lauvås, P. \& Handal, G. (1998). Hovedfagsvejledning ved universitetet $i$ Oslo. Oslo: Universitetet i Oslo.

Lyngstrøm, H. (2007). Studerendes forventninger til vejledning på skriftlige opgaver. Dansk Universitetspcedagogisk Tidsskrift, 3 , 29-32. 
Rienecker, L., Harboe, T. \& Stray Jørgensen, P. (2005). Vejledning en brugsbog for opgave- og specialevejledere på videregående uddannelser. Frederiksberg: Forlaget Samfundslitteratur.

Simonsen, B. (1997). Larer på RUC - himmel og helvede. 8. delrapport fra UNIPÆD-projektet. Roskilde: Roskilde Universitetscenter.

Simonsen, B. \& Ulriksen, L. (1998). Universitetsstudier $i$ krise. Frederiksberg: Roskilde Universitetsforlag.

Saugstad,T. (2004).Vejledning og intimtyranniet. I: J. Krejsler (red.) Padagogikken og kampen om individet. København: Hans Reitzels Forlag.

Tofteskov, J. (1996). Projektvejledning. Frederiksberg: Forlaget Samfundslitteratur.
Ulriksen, L. (2004). Den implicitte studerende. Dansk Padagogisk Tidsskrift. 2003:3.

Wichmann-Hansen, G., Eika, B. \& Mørche, A. (2007). Hvad findes der af litteratur om vejledning? - Litteratursøgning med fokus på publicerede, evidensbaserede studier. Dansk Universitetspeedagogisk Tidsskrift, 3, 11-19.

\section{Noter}

1 For en diskussion heraf se fx Ulriksen (1997); Simonsen \& Ulriksen (1998); Frello (1996); Kolmos \& Kofoed (2002); Kolmos \& Holgaard (2007). 